\title{
Factors Affecting Exclusive Breastfeeding in Cimande Village, Caringin, Bogor District
}

\author{
Purwantoro $^{1 *}$, Maryanah ${ }^{2}$, Endang Purnawati Rahayu ${ }^{3}$, Irwandi $^{4}$, Irfan Nurdiansyah $^{5}$ \\ ${ }^{1}$ Universitas Pasir Pengaraian, Indonesia \\ ${ }^{2}$ Politeknik Kesehatan Jakarta III \\ ${ }^{3}$ STIKES Hang Tuah, Pekanbaru \\ ${ }^{4}$ UIN Sunan Gunung Djati, Bandung \\ ${ }^{5}$ GoAcademica Result and Publishing \\ Corresponding Email: purwan78@gmail.com
}

\begin{abstract}
The infant must be breastfeeding primarily until he or she is six months old. However, only about $13 \%$ of moms breastfeed their babies exclusively until now. This study aimed to find out just what factors influence exclusive breastfeeding in Cimande village breastfeeding mothers. Caringin district, Bogor district. With the purposive sampling method, 80 mothers who met the entrance requirements were contacted. The data were evaluated statistically, with the Chi-Square test used to classify the factors that influence exclusive breastfeeding and logistic regression to assess the determinants that had the most significant impact on exclusive breastfeeding. According to the scientific analysis, maternal age, working status, birth order, and the support of health-care professionals all have a significant impact on exclusive breastfeeding. According to the logistic regression test, the most critical factor affecting exclusive breastfeeding is the mother's profession with $\mathrm{p}=0.008$ and $\mathrm{OR}=4.137$, which indicates that mothers who do not work have four times the chance of giving exclusive breastfeeding to their babies compared to working mothers. The reasons that affect breastfeeding mothers' ability to breastfeed exclusively in Cimande village, Caringin district, Bogor district are maternal age, employment status, baby birth order, support from health workers, and the most dominant factor is employment status.
\end{abstract}

Keywords: Effect, Exclusive Breastfeeding, Breastfeeding Mothers

\section{INTRODUCTION}

Breast milk is the perfect food for babies and contains all the nutrients needed to grow and develop for at least the first six month. Breastfeeding without additional food and other drinks for infants aged zero to 6 months is called exclusive breastfeeding In the 2017 and 2020 Indonesian Demographic and Health Survey (IDHS), more than $95 \%$ of mothers had breastfed their babies. However, breastfeeding in the first hour tends to decline $8 \%$ in 2018 to $3.7 \%$ in 2020 (Indriyanto, 2021). Based on the same study, exclusive breastfeeding coverage for 6 months decreased from $42.4 \%$ in 2017 to $39.5 \%$ in 2020 . Meanwhile, formula milk has more than tripled in five years, from $10.8 \%$ in 2017 to $32.5 \%$ in 2020 (Kartika, 2021).
When women have decided to work, women must be ready to carry out the dual roles they carry (Alianmoghaddam, 2019). This dual role is the problem. The impact of mothers working on children is comprehensive, can include health, safety, happiness, children's education, and so on (Asare, 2018). When the mother works outside the home, the child is entrusted with a sibling, or grandmother, or servant. Thus, when the mother works, the child depends on who the character replaces the mother when leaving the house. Coming home from work, tired physical and mental conditions after working all day have hampered breast milk's smooth production. This discourages working mothers from providing exclusive breastfeeding (Ahmed, 2019). 
The seminar to commemorate the 2008 World Breastfeeding Week revealed many factors that contribute to In Indonesia, one of the supportive influences is the husband, who is the closest person to the mother and plays a key role during childbirth, pregnancy, and breastfeeding after baby is born. The mother's mental condition will be affected by the husband's encouragement, affecting parenting performance (Laksono \& Kusrini, 2021). Breastfeeding mothers benefit from social and psychological services provided by their husbands (Lestari, 2021). As conveyed by her oxytocin reflex in the form of thoughts, feelings, and sensations, the mental reaction of the parent dictates between $80 \%$ to $90 \%$ of breast milk production (Bhattacharjee, 2019).

In Australia, the practice of exclusive breastfeeding has proven to be 1.5 times more successful when supported by husbands (Cascone, 2019). The success rate of breastfeeding babies up to six months increased in the study group that included fathers and mothers in breastfeeding counseling compared to the study group that was only followed by mothers (Erfiyani, 2020). These factors include knowledge, attitudes, plans for exclusive breastfeeding, parity, mother's job, husband's job, husband's education, and health workers' support (Charlick, 2019).

\section{METHOD}

This research is non-experimental quantitative research, Specifically, descriptive analysis with a cross-sectional approach, in which cause and effect factors that appear in the research object are concurrently calculated and gathered, momentarily, or only once at a time. There is no follow-up. The analytical survey method describes a situation or a design used to provide information about the prevalence, distribution, and relationships between variables in a population without any intervention from the researcher (Monteiro, 2017).

Respondents in this sample were all Cimande village mothers with children aged 0 to 1 year who met the study's inclusion criterion. Inclusion criteria include mothers who have children aged 0 to 1 year and reside in the Cimande village area and mothers willing to be respondents. Meanwhile, the exclusion criteria include mothers who do not have a health service system (posyandu) in their spot and mothers who have a cesarean section. Purposive sampling was used in this analysis, and the total number of respondents used during data gathering was 80 . Mother and baby socio-demographics (mother's age, education level, job status, baby birth order), mother's awareness of breastfeeding, husband's encouragement, support from health professionals, socio-culture, and exclusive breastfeeding were all part of the questionnaire (Nkoka, 2019).

\section{RESULT AND DISCUSSION}

Respondents' descriptions of research variables, Table 1 shows the age, education level, job status, birth order of the infant, mother's experience, husband's assistance, support from health staff, and socio-culture of the mother.

Table 1 Description of Respondents According to Research Variables

\begin{tabular}{|c|c|c|c|}
\hline Independent Variable & Category & n & $\%$ \\
\hline \multirow{2}{*}{ Age } & $<20-30$ years & 52 & 65 \\
& $>30$ years & 28 & 35 \\
\hline \multirow{2}{*}{ Level of education } & High & 69 & 86 \\
& Low & 11 & 14 \\
\hline \multirow{2}{*}{ Job status } & Work & 42 & 52 \\
& Does not work & 48 & 48 \\
\hline \multirow{2}{*}{ Order of Birth of a Baby } & The first child & 50 \\
Level of Knowledge About & Apart from the First Child & 69 & 50 \\
Breastfeeding & Good & 11 & 14 \\
\hline \multirow{2}{*}{ Husband's Support } & Less & 69 & 86 \\
\multirow{2}{*}{ Health Officer Support } & Support/ & 11 & 14 \\
\hline \multirow{2}{*}{ Socio-cultural } & Less Support & 6 & 92 \\
& Support/ & 71 & 89 \\
\hline
\end{tabular}


The relationship between the independent and dependent variables through the crosstable can be seen in table 2. A total of 35 mothers of 52 mothers aged $<20-30$ years $(67 \%)$ did not exclusively breastfeed, and 16 mothers of 28 mothers were over 30 years of age $(57,1 \%)$ exclusively breastfeeding. The chi-square test's statistical test is because no cell has an expected value of less than 5 , and a $p=0.034$ is obtained. The probability value is $5 \%(0.05)$ and means the $p$-value $<0.05$ so that this value demonstrates that there is a correlation between age and exclusive parenting (Nugrahaeni, 2020).

A total of 41 mothers of 69 highly educated mothers $(59.4 \%)$ did not exclusively breastfeed, and five mothers of 11 mothers with low education (45.5\%) exclusively breastfed their babies (Ogbo, 2019). The Fisher Exact Test's statistical test is because there is one cell with an expected value of less than 5. The p-value of the Fisher test is 0.754 . A total of 31 mothers of 42 working mothers $(73.8 \%)$ ) did not give exclusive breastfeeding, from 22 mothers of 38 unemployed mothers $(57.9 \%)$ who gave exclusive breastfeeding. The statistical test used was the Chi-Square test because no cell had an expected value of less than 5 , and the p-value was obtained $=$ 0.004 (Octaviyani \& Budiono, 2020). The probability value is 0.05 and means that the $p$-value is $<0.05$. Consequently, this importance suggests that a woman's work status has a significant effect on her breastfeed exclusively (Nukpezah, 2018).

In the study, eight variables were thought to be related to and influence exclusive breastfeeding, namely age, education level, employment status, birth order, level of knowledge about breastfeeding, husband's support, support from health workers, and socio-culture. The eight variables were first carried out by bivariate analysis with the dependent variable to create a multivariate model, namely exclusive breastfeeding. The variable which when the $G$ test (Log-Likelihood ratio) is carried out has $p<0.25$ and has substantial significance can be used as candidates to be included in the multivariate model (Pridasari \& Salim, 2021)

Table 2 Factors Affecting Exclusive Breastfeeding in Breastfeeding Mothers $(n=80)$

\begin{tabular}{|c|c|c|c|c|c|c|}
\hline \multirow[b]{2}{*}{ Variable } & \multirow[b]{2}{*}{ Category } & \multicolumn{2}{|c|}{ Breastfeeding } & \multirow[b]{2}{*}{$x^{2}$} & \multirow{2}{*}{$\begin{array}{c}\mathbf{P} \\
\text { value }\end{array}$} & \multirow{2}{*}{$\begin{array}{c}\text { Fisher's } \\
\text { Exact } \\
\text { Test }\end{array}$} \\
\hline & & Exclusive & $\begin{array}{c}\text { Non } \\
\text { Exclusive }\end{array}$ & & & \\
\hline \multirow{2}{*}{ Age } & $<20-30$ Age & $17(32,7 \%)$ & $35(67,3 \%)$ & \multirow{2}{*}{4,490} & \multirow{2}{*}{0,034} & \multirow{2}{*}{0,056} \\
\hline & $>30$ Age & $16(57,1 \%)$ & $12(42,9 \%)$ & & & \\
\hline \multirow{2}{*}{ Level of education } & High & $28(40,6 \%)$ & $41(59,4 \%)$ & \multirow{2}{*}{0,093} & \multirow{2}{*}{0,760} & \multirow{2}{*}{0,754} \\
\hline & Low & $5(45,5 \%)$ & $6(54,5 \%)$ & & & \\
\hline \multirow{2}{*}{ Job-status } & Work & $11(26,2 \%)$ & $31(73,8 \%)$ & \multirow{2}{*}{8,275} & \multirow{2}{*}{0,004} & \multirow{2}{*}{0,006} \\
\hline & Does not work & $22(57,9 \%)$ & $16(42,1 \%)$ & & & \\
\hline \multirow{2}{*}{$\begin{array}{c}\text { Order of Birth of a } \\
\text { Baby }\end{array}$} & The first child & $12(30 \%)$ & $28(70 \%)$ & \multirow{2}{*}{4,178} & \multirow{2}{*}{0,041} & \multirow{2}{*}{0,069} \\
\hline & $\begin{array}{l}\text { Besides the first } \\
\text { child }\end{array}$ & $21(52,5 \%)$ & $19(47,5 \%)$ & & & \\
\hline \multirow{2}{*}{$\begin{array}{c}\text { Level of } \\
\text { Knowledge } \\
\text { About } \\
\text { Breastfeeding } \\
\end{array}$} & Good & $30(27,3 \%)$ & $39(56,5 \%)$ & \multirow[b]{2}{*}{1,028} & \multirow[b]{2}{*}{0,311} & \multirow[b]{2}{*}{0,511} \\
\hline & Less & $3(27,3 \%)$ & $8(72,7 \%)$ & & & \\
\hline \multirow{2}{*}{$\begin{array}{c}\text { Husband's } \\
\text { Support }\end{array}$} & Support & $28(40.6 \%)$ & $41(59,4 \%)$ & \multirow{2}{*}{0,093} & \multirow{2}{*}{0,760} & \multirow{2}{*}{0,754} \\
\hline & Less Support & $5(45,5 \%)$ & $6(54,5 \%)$ & & & \\
\hline Vaginal Health & Support & $33(44,6 \%)$ & $41(55,4 \%)$ & 4,554 & 0,033 & 0,039 \\
\hline
\end{tabular}




\begin{tabular}{|c|c|c|c|c|c|c|}
\hline $\begin{array}{c}\text { Officer } \\
\text { Support }\end{array}$ & Less Support & $0(0 \%)$ & $6(100 \%)$ & & & \\
\hline & Support & $31(43,7 \%)$ & $40(56,3 \%)$ & & & \\
\hline Socio-cultural & Less Support & $2(22,2 \%)$ & $7(77,8 \%)$ & 1,515 & 0,218 & 0,294 \\
\hline
\end{tabular}

The bivariate analysis results in table 2 show five independent variables whose $\mathrm{p}$-value is $<0.25$, namely age, employment status, birth-order of babies, support from health workers, and socio-culture. The variables continue to enter the multivariate model (Robinson, 2019). The multivariate analysis aims to obtain the best model in determining the determinants of exclusive breastfeeding. The optimal model will consider two measurements: the sig value-likelihood ratio $(\mathrm{p}=0.05)$ and the sig value $(\mathrm{p}=0.05)$. The model is chosen hierarchically, with all independent variables (that passed the test) being entered into the model and evaluated together. The variables with the lowest p-values are excluded from the model first, followed by the variables with the highest $\mathrm{p}$-values (Ratnayake, 2018).

Also, for working mothers, the short period of maternity leave or childbirth means that they have to return to work before the entire breastfeeding period ends. This interferes with efforts to provide exclusive breastfeeding. Exclusive breastfeeding must be followed for 6 months without intervention in other foods and beverages, while maternity and maternity leave is only given for three months (Safitri \& Citra, 2020).

The statistical analysis test showed a significant effect between the order of the baby's birth and exclusive breastfeeding. Especially those with their first experience of being a mother, mothers are usually susceptible to their children. This makes mothers very vulnerable to various provocations and persuasion. Various comments that are less or not 'friendly' exclusive breastfeeding made by multiple parties (family, work friends, or neighbors) can make the motherless or even insecure, which in turn becomes demotivated to provide exclusive breastfeeding (Sinurat, 2020). According to Hurlock, parents who have had experience caring for their children before, by taking courses given in clinics before birth or having cared for previous children, are more confident in carrying out the role of parents than those who do not have such experience (Senghore, 2018). Parents who set norms of behavior based on what was done to their previous children at various age levels, tend to judge newborns accordingly. Likewise, in terms of breastfeeding, if the mother gets a good experience from exclusive breastfeeding for her first child, then the next child will also do the same thing.

\section{CONCLUSION}

According to the study, the age of the woman, her job status, the order in which the baby is born, and the assistance of health workers are all factors that affect exclusive breastfeeding for breastfeeding mothers in Cimande village, Caringin district, Bogor district. The mother's job status has the most significant impact on exclusive breastfeeding for breastfeeding mothers in Cimande village, Caringin county, Bogor district, with respondents who do not provide exclusive breastfeeding to their babies four times more than respondents that operate.

\section{REFERENCES}

[1] Alianmoghaddam, N., Phibbs, S., \& Benn, C. (2019). "I did a lot of Googling": A qualitative study of exclusive breastfeeding support through social media. Women and Birth, 32(2), 147-156.

[2] Asare, B. Y. A., Preko, J. V., Baafi, D., \& Dwumfour-Asare, B. (2018). Breastfeeding practices and determinants of exclusive breastfeeding in a cross-sectional study at a child welfare clinic in Tema Manhean, Ghana. International breastfeeding journal, 13(1), 1-9.

[3] Bhattacharjee, N. V., Schaeffer, L. E., Marczak, L. B., Ross, J. M., Swartz, S. J., Albright, J., \& Hay, S. I. (2019). Mapping exclusive breastfeeding in Africa between 2000 and 2017. Nature medicine, 25(8), 1205-1212.

[4] Cascone, D., Tomassoni, D., Napolitano, F., \& Di Giuseppe, G. (2019). Evaluation of knowledge, attitudes, and practices about 
exclusive breastfeeding among women in Italy. International journal of environmental research and public health, 16(12), 2118-2145.

[5] Charlick, S. J., McKellar, L., Gordon, A. L., \& Pincombe, J. (2019). The private journey: An interpretative phenomenological analysis of exclusive breastfeeding. Women and Birth, 32(1), 34-42.

[6] Erfiyani, R. I. (2020). Faktor Yang Berhubungan Dengan Perilaku Pemberian ASI Eksklusif di Kelurahan Pegirian Kecamatan Semampir Kota Surabaya. Medical Technology and Public Health Journal, 4(1), 91-100.

[7] Indrianto, I., \& Sohibien, G. P. D. (2021). Pemodelan Survival untuk Ketahanan Pemberian ASI Eksklusif di Indonesia pada Tahun 2018. In PRISMA, Prosiding Seminar Nasional Matematika, 4(3), 705-717.

[8] Kartika, L., Tanggulungan, F. F., Sinurat, R. P. F., Tambunan, A. T., \& Aiba, S. (2021). Relationship between Mothers' Knowledge and Exclusive Breastfeeding Behavior in One Private Hospital in West Indonesia. International Journal of Nursing and Health Services (IJNHS), 4(1), 18.

[9] Laksono, A. D., Wulandari, R. D., Ibad, M., \& Kusrini, I. (2021). The effects of mother's education on achieving exclusive breastfeeding in Indonesia. BMC Public Health, 21(1), 1-6.

[10] Lestari, E. S. (2021). Hubungan Asi Eksklusif dan BBLR dalam Pertumbuhan Bayi Usia 1-2 Tahun. Syntax, 3(1), 98-132.

[11] Monteiro, F. R., Buccini, G. D. S., Venâncio, S. I., \& Da, C. T. H. (2017). Influence of maternity leave on exclusive breastfeeding. Jornal de pediatria, 93(5), 475-481.

[12] Nkoka, O., Ntenda, P. A., Kanje, V., Milanzi, E. B., \& Arora, A. (2019). Determinants of timely initiation of breast milk and exclusive breastfeeding in Malawi: a population-based cross-sectional study. International breastfeeding journal, 14(1), 1-9.

[13] Nugraheni, D., Nuryanto, N., Wijayanti, H. S., Panunggal, B., \& Syauqy, A. (2020). Asi Eksklusif Dan Asupan Energi Berhubungan Dengan Kejadian Stunting Pada Usia 6-24 Bulan Di Jawa Tengah. Journal of Nutrition College, 9(2), 106-113.
[14] Nukpezah, R. N., Nuvor, S. V., \& Ninnoni, J. (2018). Knowledge and practice of exclusive breastfeeding among mothers in the tamale metropolis of Ghana. Reproductive health, 15(1), $1-9$.

[15] Octaviyani, M., \& Budiono, I. (2020). Praktik Pemberian ASI Eksklusif di Wilayah Kerja Puskesmas. HIGEIA (Journal of Public Health Research and Development), 4(3), 435-447.

[16] Ogbo, F. A., Dhami, M. V., Awosemo, A. O., Olusanya, B. O., Olusanya, J., Osuagwu, U. L., \& Agho, K. E. (2019). Regional prevalence and determinants of exclusive breastfeeding in India. International breastfeeding journal, 14(1), $1-12$.

[17] Pridasari, A., \& Salim, L. A. (2021). The Influences of Antenatal Care, Postnatal Care, and Early Initiation of Breastfeeding on an Exclusive Breastfeeding Pattern in the Working Area of Manukan Kulon Public Health Center at Surabaya City. Medico-Legal Update, 21(1), 129-134.

[18] Ratnayake, H. E., \& Rowel, D. (2018). Prevalence of exclusive breastfeeding and barriers for its continuation up to six months in Kandy district, Sri Lanka. International breastfeeding journal, 13(1), 1-8.

[19] Robinson, H., Buccini, G., Curry, L., \& Perez, E. R. (2019). The World Health Organization Code and exclusive breastfeeding in China, India, and Vietnam. Maternal \& child nutrition, 15(1), 126185.

[20] Safitri, M. G., \& Citra, A. F. (2020). Perceived social support dan breastfeeding self-efficacy pada ibu menyusui asi eksklusif. Jurnal Psikologi, 12(2), 108-119.

[21] Senghore, T., Omotosho, T. A., Ceesay, O., \& Williams, D. C. H. (2018). Predictors of exclusive breastfeeding knowledge and intention to or practice of exclusive breastfeeding among antenatal and postnatal women receiving routine care: a cross-sectional study. International breastfeeding journal, 13(1), 1-8.

[22] Sinurat, R., Nevrita, N., \& Hindrasti, N. E. K. (2020). Identifikasi tingkat kemampuan berpikir kritis siswa pada materi ASI eksklusif dan program keluarga berencana. Jurnal IPA \& Pembelajaran IPA, 4(1), 60-69. 